\title{
The Effect of Sage Essential Oil on the Compositional Quality of Anchovy Fish Burger During Freeze Storage
}

\author{
Ahmed E. E. Gomma, Tarek M.A. Srour and Ahmed E. M. Abdalla \\ Faculty of Agriculture, Saba Basha, Alexandria University
}

\begin{abstract}
The purpose of this study was to investigate the compositional quality and sensory evaluation of prepared European anchovy fish burgers supplemented with extracted sage essential oil $(2 \%, 4 \%$ and $6 \%)$ during frozen storage at $-18{ }^{\circ} \mathrm{C}$ for 4 months. Sage essential oil was extracted by hydrodistillation method and analyzed with GC-MS. The analysis of proximate chemical composition, fatty acid profile and sensory evaluation were carried out on prepared fish burger samples at zero time and after 4 month storage at $-18{ }^{\circ} \mathrm{C}$, while the analysis of fish burgers quality (peroxide value PV and free fatty acid FFA) were carried out periodically every month up to 4 month storage period. There was a significant decrease in moisture, protein and lipid of fish burgers after 4 month storage at $-18{ }^{\circ} \mathrm{C}$. The obtained results showed that $\mathrm{PV}$ and FFA were less increase in fish burger samples supplemented with sage essential oil than control samples. The investigated sage essential oil caused a significant improve the quality of fish burgers through retarded the spoilage and enhancement the polyunsaturated fatty acids of fish burgers during frozen storage, as compared to the control sample. These results could be due to the antioxidative effect of bioactive compounds ( $\alpha$-thujone, camphor, $\alpha$-pinene and $\beta$-thujone) found in sage essential oil. In conclusion, the supplementation of anchovy fish burgers with sage essential oil showed a positive effect on the compositional quality and shelf life, anchovy fish burgers were of high quality and high acceptance even after 4 month storage at $-18^{\circ} \mathrm{C}$.
\end{abstract}

Keywords: fish burger, anchovy, sage, compositional quality, sensory evaluation

\section{INTRODUCTION}

Fish flesh has unique characteristics as having high protein content with balanced profile of amino acids, polyunsaturated and essential fatty acids with $\omega-3$ and $\omega-6$ series of fatty acids and low level of saturated fat and cholesterol (Edwards and Kaewpaitoon 1981, Gomma, 2005 and El-Lahamy et al., 2019). Polyunsaturated fatty acids especially eicosapentaenoic acid (C20:5n3, EPA) and docosahexaenoic acid (C22:6n3, DHA) can reduce the risk of cardiovascular disease, improve mental and visual functions and are involved in inflammatory responses (Abuajah et al., 2014). They may also lead to a decrease in body fat over time and reduce obesity risk (Merched et al., 2008). Accordingly, consumption of fish and fishery products are increasing day by day due to increasing awareness of the consumers on health issues (Husein et al., 2019).

The European anchovy (Engraulis encrasicolus) is a small pelagic fish which is widely distributed from the North Sea to Central Africa, and throughout the Mediterranean Sea (Pauly and Froese 2012). There is a large quantity of very small fish landed as by-catch which do not find a ready market as anchovy fresh fish in Egypt. European anchovies are small, common saltwater forage fish that are used as human food, fish bait and fish oil (Yerlikaya et al., 2005 and Türkiye Istatistik Kurumu, 2013). The European anchovy is used as many varieties of food 
from dessert to salty food. The European anchovy contains high-quality of lipid and protein and also highly-balanced distribution in terms of vitamins. It is kind a fish, rich in polyunsaturated fatty acids (Güner et al., 1998 and Taskaya et al., 2018). It is reported that nearly $30 \%$ of the total fatty acids in the European anchovy are docosahexaenoic acid (DHA) and eicosapentaenoic acid (EPA) (Güner et al., 1998 and Qendouci et al., 2018).

In recent years, the preference of the consumers has significantly directed towards the fast food consumption since there has been a rapid urbanization and an increase in working women population (Obiero et al., 2019). There have been some studies on the production and quality stability of the fishery fast food products including fish cake, fish crackers, fish balls and fish burgers (Ihm et al. 1992a and 1992b, Lazos 1996 and Shahin et al., 2016).

Fish burgers are very popular and tasty item in fast food industry, which are increasing in popularity and have extensively developed in the world food market. Different studies have been conducted to determine the quality of fish burgers (Tokur et al., 2004, 2006, Al-Bulushi et al., 2005, Hassab Alla et al., 2009 and Mattje et al., 2019). More research works has proved that even fish burgers stored at frozen temperatures can undergo undesirable quality changes (Hall, 2011 and Jessen et al., 2014) due to oxidative rancidity and protein denaturation (Al-Bulushi et al., 2005, Alizadeh et al., 2007, Mexis et al., 2009 and Atitallah et al., 2019).

Fish and their products are very perishable foods due to their high water activity, the presence of polyunsaturated fatty acids and neutral pH (Fogaça and Sant'ana, 2009). The susceptibility of fish oxidation depends not only on fish species, the amount of total lipids and the composition of fatty acids as well as their location in fish muscle tissue (Raeisi et al., 2015). The quality changes due to lipid oxidation results in undesirable changes in taste, odor, color, and acceptability. Additionally, the formation of toxic compounds may occur, decreasing the food safety and nutritional quality, and causing health damages to the consumer (Ali et al., 2019 a and b).

Consequently, employing natural preservatives, antimicrobial, antioxidant substances and stabilisers in the products formulations seems quite logical and necessary. Spices and herbs and their essential extracts have been added to food since ancient times, not only as flavoring agents but also as folk medicine and food preservatives (Nakatani, 1994, Singh et al., 2005, Corbo et al., 2009 and Ozogul and Ucar, 2012). They have been applied in many fish species in showing antimicrobial and antioxidant activities against food-borne pathogens and extending the shelf life of the fish (Abdeldiem et al., 2017, Hassoun and Coban, 2017, Dolea et al., 2018 and Saleem et al., 2019). Plants from Lamiaceae family, such as rosemary, thyme, sage, oregano and peppermint, have been recognized for their potent antioxidant activity (Babovic et al., 2010). 
Sage (Salvia officinalis) is a rich source of phytochemicals including phenolic acids, polyphenols, flavonoid glycosides, anthocyanins, sesquiterpenoids, diterpenoids, sesterterpenes and triterpenes (Shan et al., 2005, Wojdylo et al., 2007 and Sepahvand et al., 2014). Some researchers have reported that sage, or sage extracts, can effectively retard lipid oxidation in different meat and fish products (Estevez et al., 2007, Fasseas et al., 2008, Mariutti et al., 2008 and 2011, Zhang et al., 2013 and Mizi et al., 2019).

Therefore, the objective of this study was to investigate the effects of different levels of sage extract on physicochemical properties and nutritional value aspects for raw European anchovy fish burgers during frozen storage at $-18^{\circ} \mathrm{C}$ for 4 months.

\section{MATRIAL AND METHODS}

\section{Materials}

Leaves of sage (Salvia officinalis L.) were collected from Siwa Oasis, Egypt, in September 2018.

Twenty kilogram of European anchovy (Engraulis encrasicolus) fish samples were obtained during the autumn season $r .1 \wedge$ from artisanal fishermen in ElMaadia port fishing communities, located in Beheira governorate, Egypt. Fish samples were transported in ice boxes to Food Science Laboratory, Faculty of Agriculture, Saba Basha, Alexandria University, Egypt. Fish samples were weighed, homogenized and kept in a clean well plastic bag and stored at $4{ }^{\circ} \mathrm{C}$ till analysis.

\section{Fish burger preparation}

The European Anchovy fish were weighed and then washed with water, beheaded, gutted and washed in iced condition. Fish were weighed and mixed in order to obtain a fish burger with ratio fish/other ingredients of 55:45, 53:47, 51:49 and 49:51 (w/w). In order to obtain a product with balanced composition of micro and macronutrients different ingredients of vegetable and animal origin such as boiled and crushed potato, Soybean, sage and spices (white pepper and cinnamon, in particular) were added as described in Table 1. The fish burgers were prepared manually for a final weight of $100 \pm 5 \mathrm{~g}$, packed in high barrier plastic bags (Nylon/Polyethylene) and divided into control samples and three different concentration of the sage essential oil $(2,4$ and $6 \%)$ were supplemented to fish burgers, respectively. All samples (control without sage extract and three treatments $\mathrm{T} 1, \mathrm{~T} 2$ and $\mathrm{T} 3$ with $2 \%, 4 \%$ and $6 \%$ sage extract, respectively) were stored under freezing temperature $\left(-18^{\circ} \mathrm{C}\right)$. 
Table (1). Recipe of European Anchovy fish burgers supplemented with different levels of sage extract

\begin{tabular}{lcccc}
\hline \multirow{2}{*}{ Ingredients } & \multicolumn{4}{c}{ Treatments, sage essential oil } \\
\cline { 2 - 5 } & Control (0\%) & $\mathbf{2 \%}$ & $\mathbf{4 \%}$ & $\mathbf{6 \%}$ \\
\hline Minced Fish & 55 & 53 & 51 & 49 \\
Potato & 15 & 15 & 15 & 15 \\
Soy & 10 & 10 & 10 & 10 \\
Flour & 10 & 10 & 10 & 10 \\
Spices & 3 & 3 & 3 & 3 \\
Salt & 2 & 2 & 2 & 2 \\
Sugar & 0.5 & 0.5 & 0.5 & 0.5 \\
Garlic & 1 & 1 & 1 & 1 \\
Onion & 1 & 1 & 1 & 1 \\
Pepper & 1 & 1 & 1 & 1 \\
Cumin & 1.5 & 1.5 & 1.5 & 6 \\
Sage essential oil & 0 & 2 & 4 & \\
\hline
\end{tabular}

\section{Methods}

Extraction of essential oil and Gas chromatography-Mass Spectrometry (GCMS) analysis

Five hundred grams of sage fresh leaves were submitted to hydrodistillation (with $1000 \mathrm{~mL}$ of water) in a Clevenger-type apparatus for 72 minutes without collecting solvent (Porte and Godoy, 2008). The collected essential oil was carried out using gas chromatography-mass spectrometry instrument stands at the Central Laboratories, National Research Center with the following specifications. Instrument: a TRACE GC Ultra Gas Chromatographs (THERMO Scientific Corp., USA), coupled with a THERMO mass spectrometer detector (ISQ Single Quadrupole Mass Spectrometer).The GC/MS system was equipped with a TGWAX MS column (30 m x $0.25 \mathrm{~mm}$ i.d., $0.25 \mu \mathrm{m}$ film thickness). Analyses were carried out using helium as carrier gas at a flow rate of $1.0 \mathrm{~mL} / \mathrm{min}$ and a split ratio of $1: 10$ using the following temperature program: $40^{\circ} \mathrm{C}$ for $1 \mathrm{~min}$; rising at $4.0^{\circ} \mathrm{C} / \mathrm{min}$ to $160^{\circ} \mathrm{C}$ and held for $6 \mathrm{~min}$; rising at $6 \mathrm{C} / \mathrm{min}$ to $210 \mathrm{C}$ and held for $1 \mathrm{~min}$. The injector and detector were held at $210^{\circ} \mathrm{C}$. Diluted samples $(1: 10$ hexane, $\mathrm{v} / \mathrm{v}$ ) of $0.2 \mu \mathrm{L}$ of the mixtures were always injected. Mass spectra were obtained by electron ionization (El) at $70 \mathrm{eV}$, using a spectral range of $\mathrm{m} / \mathrm{z} 40-450$. Most of the compounds were identified using two different analytical methods: relative retention time and mass spectra (authentic chemicals.

\section{Proximate chemical composition analyses}

Moisture, Protein, fat and ash of the fish samples were determined according to the standard methods of AOAC (2007).

\section{Extraction of total lipids}

Lipid was extracted from prepared anchovy fish burger samples with a mixture of chloroform / methanol (2: $1 \mathrm{v} / \mathrm{v})$ according to the method described by Folch et al. (1957). 


\section{Peroxide value (PV)}

The peroxide value as an indicator of primary lipid oxidation was determined in lipids extracted from different fish burgers according to the method presented by Kirk and Sawyer (1991). The results were expressed as $\mathrm{mEq}$ active oxygen per $\mathrm{kg}$ extracted lipid.

\section{Free Fatty Acid (FFA)}

The (FFA) contents of the lipid were determined in lipids extracted from different fish burgers according to Kirk and Sawyer (1991) by titration in ethanol against phenolphethalene with $0.02 \mathrm{M}$ sodium hydroxide and expressed as percentage oleic acid.

\section{Fatty acid profile}

Preparation of fatty acid methyl esters of total lipids extracted from control and burger samples were performed as follows: Methylene chloride $(100 \mu \mathrm{l})$ and 1 $\mathrm{ml} 0.5 \mathrm{M} \mathrm{NaOH}$ in methanol were added to oil extracts in a test-tube and heated in a water bath at $90^{\circ} \mathrm{C}$ for $10 \mathrm{~min}$. The test tubes were removed from the water bath and allowed to cool before addition of $1 \mathrm{ml} \mathrm{14 \%} \mathrm{BF}_{3}$ in methanol. The test tubes are heated again in a water bath for $90^{\circ} \mathrm{C}$ for $10 \mathrm{~min}$ and cooled at room temperature. One $\mathrm{ml}$ distilled water and 200-500 $\mu \mathrm{l}$ hexane was added to the test tubes and then FAME was extracted by vigorous shaking for about $1 \mathrm{~min}$. Following centrifugation, the top layer was transferred into a sample bottle for GC analysis (Luddy et al., 1960). A sample of $25 \mathrm{mg}$ total lipid was transferred into a screw-cap vial, with $2.5 \mathrm{ml}$ methanolic $\mathrm{H}_{2} \mathrm{SO}_{4}$ and $1 \mathrm{ml}$ benzene. The vial converted under a steam of nitrogen gas before heating in oven at $90^{\circ} \mathrm{C}$ for $1.5 \mathrm{hr}$.

Analysis of fatty acid was carried out by Gas Liquid Chromatography (GLC) using Hewlett Packard (HP) 6890 GC with $1 \mu$ injection and flame ionization detector (FID) at $250^{\circ} \mathrm{C}$ temperature. The fatty acid methyl siloxane capillary column Hp -5 (30m x $0.32 \mu \mathrm{m}$ ID, $0.25 \mu \mathrm{m}$ film thickness) was used. Nitrogen was used as the carrier gas $(0.8 \mathrm{ml} / \mathrm{min}$ gas flow). The injection temperature was $220^{\circ} \mathrm{C}$ splitess mode. The temperature program was $200^{\circ} \mathrm{C}$ for zero hold min $\left(10^{\circ} \mathrm{C} / \mathrm{min}\right)$ and held at this temperature for $9 \mathrm{~min}$. The total run time was $26 \mathrm{~min}$. A standard mixture of methyl esters was analyzed under identical conditions prior to running the samples. The retention times of the unknown samples of methyl esters were compared with those of standard. The relative percentage of the area for each peak was obtained.

\section{Sensory analysis}

The sensory evaluation of fish burgers was done by a five-member trained panel from the university. To conduct sensory analyses, fried fish burgers were evaluated with respect to their colour, odour, taste, texture, and overall acceptability. The fish burgers were fried separately by deep-frying in sunflower oil at $160^{\circ} \mathrm{C}$ for 5 min. (frying was carried out immediately during evaluation) were evaluated at zero time immediately after preparation and finally at the end of storage period. After frying, they were cooled and samples were served to the panelists who were asked to evaluate on a 10-point hedonic scale ranging from 
very poor (0) to very good (10) where: less than 2 is very poor, 2- 4 is poor, 5-6 is normal, 7-8 is good, and 9-10 is very good (Kurtcan and Gonul, 1987).

\section{RESULTS AND DISCUSSION}

\section{Chemical composition of sage essential oil}

The essential oil of sage growing in Siwa Oasis, Egypt was subjected to detailed GC/MS analysis. Exactly 29 compounds were identified, representing $96.52 \%$ of the total essential oil (Table 2). The major compounds were camphor $26.14 \%$, 1,8-cineole $18.06 \%$ and a-thujone 15.14\%. Other important compounds were $\beta$-thujone $(4.35 \%)$, $\alpha$-humulene $(4.28 \%)$, manoyl oxide $(4.26 \%), \quad \beta$ caryophyllene $(4.02 \%)$, $\gamma$-selinene $(3.66 \%)$, limonene $(3.52 \%)$, borneol $(3.50 \%)$, Viridiflorol (1.45\%) and a-terpineol (1.40\%). Other compounds were detected in less than 1\%. These results were in agreement with Said-Al Ahl et al. (2015) and Ben Khedher et al. (2017).

Table (2). Chemical composition of S. officinalis leaves essential oil

\begin{tabular}{|c|c|c|c|}
\hline No & Compound name & RT (min) & Peak area (\%) \\
\hline 1 & Camphene & 956 & 0.46 \\
\hline 2 & $\beta$-Pinene & 981 & 0.67 \\
\hline 3 & $\beta$-Myrcene & 994 & 0.48 \\
\hline 4 & $\alpha$-Terpinene & 1022 & 0.31 \\
\hline 5 & 1.8-Cineole & 1034 & 18.06 \\
\hline 6 & Limonene & 1044 & 3.52 \\
\hline 7 & $\alpha$-Terpinolene & 1090 & 0.65 \\
\hline 8 & Linalool & 1098 & 0.33 \\
\hline 9 & $\alpha$-Thujone & 1119 & 15.14 \\
\hline 10 & $\beta$-Thujone & 1124 & 4.35 \\
\hline 11 & Camphor & 1150 & 26.14 \\
\hline 12 & Borneol & 1173 & 3.50 \\
\hline 13 & $\alpha$-Terpineol & 1195 & 1.40 \\
\hline 14 & Myrtenol & 1204 & 0.38 \\
\hline 15 & Bornyl acetate $\alpha$ & 1292 & 0.71 \\
\hline 16 & $\beta$-Patchoulene & 1377 & 0.31 \\
\hline 17 & $\alpha$-bourbonene & 1393 & 0.25 \\
\hline 18 & $\beta$-bourbonene & 1396 & 0.27 \\
\hline 19 & a-Gurjenene & 1411 & 0.22 \\
\hline 20 & Sinularene & 1422 & 0.21 \\
\hline 21 & Calarene & 1427 & 0.16 \\
\hline 22 & $\beta$-Caryophyllene & 1433 & 4.02 \\
\hline 23 & a-Humulene & 1465 & 4.28 \\
\hline 24 & $\alpha$-amorphene & 1489 & 0.31 \\
\hline 25 & $\beta$-Himachalene & 1496 & 0.60 \\
\hline 26 & Y-selinene & 1522 & 3.66 \\
\hline 27 & manoyl oxide & 1575 & 4.26 \\
\hline 28 & Viridiflorol & 1615 & 1.45 \\
\hline \multirow[t]{2}{*}{29} & Epimanool & 1912 & 0.42 \\
\hline & Total identified compounds & & 96.52 \\
\hline
\end{tabular}




\section{Proximate chemical composition of European Anchovy fish burgers}

Chemical analysis was carried in the prepared fish burger samples before and after 4 month storage at $-18{ }^{\circ} \mathrm{C}$ to determine changes occurred in moisture, protein, fat and ash and contents. Nitrogen free extracts (NFE) were determined by differences.

In control fish burger and three treatments supplemented with sage essential oil, the values of moisture content significantly decreased after four month storage at $-18{ }^{\circ} \mathrm{C}$ (Table 3). These results are in agreement with many authors as Vanitha et al. (2015 and 2016) and Roomiani et al. (2019). This decrease in moisture content was attributed to the sublimation of ice in frozen storage and the loss of drip during thawing process (El-Lahamy et al., 2019). Meanwhile, in contrary to these findings, in a study made on crab, Zamir et al. (1998) found an increasing trend in moisture content during storage and attributed this increase to the loss of water holding capacity of tissue.

The results indicated that protein contents of control and formulated burgers samples significantly decreased after four month storage at $-18{ }^{\circ} \mathrm{C}$. Abo-Taleb (1997) and El-Lahamy et al. (2019) reported that the changes in protein content during frozen storage may be due to the loss of some volatile nitrogenous compounds during frozen storage and protein hydrolysis by enzymes which enhanced the loss of water soluble nitrogen with separated drip. Gandotra et al., (2012) attributed protein loss observed during frozen storage of (Labeo rohita) to the leaching effect on amino acid and water-soluble protein during thawing, process.

The results indicated that total lipid contents of control and formulated burgers samples significantly decreased after four month storage at $-18{ }^{\circ} \mathrm{C}$. However, the burger samples formulated without adding sage extract (control) showed faster rates of lipid decreasing after 4 month storage under the same conditions. Similar results reported by Ibrahim and El-Sherif (2008) and El-Lahamy et al. (2019). The decreasing in fat content might be due to oxidation and hydrolysis of lipids which result in the formation of some volatile compounds as aldehydes and ketones. Same finding was mentioned by (Gandotra et al., 2012).

The results indicated that ash contents of control and formulated burgers samples significantly increased after four month storage at $-18{ }^{\circ} \mathrm{C}$. Similar observation was found during frozen storage of some fish products (Ibrahim and El-Sherif, 2008 and El-Lahamy et al., 2019). The increase in ash contents of fish products during frozen storage might be attributed to the loss recorded in the concentration of protein and fat content which reflected the increasing found in ash contents.

The increase in nitrogen free extract contents of fish products may be due to the decrease occurred in moisture, protein and fat contents during frozen storage. The variation in the chemical composition of fish is related to nutrition, living area, 
fish size, catching season, seasonal and sexual variations as well as other environmental conditions (Gandotra et al., 2012).

\section{Rancidity of extracted oil from European Anchovy fish burgers Peroxide Value (PV)}

The chemical spoilage associated with fish during storage is mainly due to fish lipid degradation (auto-oxidation). In general, fish have high degree of unsaturated lipids than other food commodities. Fish lipids are subjected to two main changes, lipolysis and auto-oxidation. The main reactants in these processes involves atmospheric oxygen and fish unsaturated lipids, leading to the formation of hydroperoxides, associated with tasteless, flavor and accompanied by brown yellow discoloration of the fish tissue. Upon further degradation of hydroperoxides are the formation of strong rancid flavors e.g. aldehydes and ketones, usually associated with spoilt fatty fish species (Khidhir et al., 2013).

Several lipid oxidation indices were assessed to follow up the development of oxidation in frozen state. Peroxide value showed primary oxidation products (Ali et al., 2019 a and b). The peroxide test is a measure of the formation of hydroperoxides. An increase in the PV is good index of the earlier stages of oxidation which on oxidation proceeds and peroxides decrease at final stages and the PV can start to fall (Yerlikaya et al., 2005). When the peroxide value exceeded 10 meq oxygen/ kg fat of fish or meat, the meat is then considered unfit for human consumption or refused (Khidhir et al., 2013).

Peroxide values were measured in extracted oil from European anchovy fish burger samples stored at temperatures $-18{ }^{\circ} \mathrm{C}$ for four month (Table 4). Peroxide values $\left(\mathrm{meqO}_{2} / \mathrm{kg}\right)$ of control and all the samples supplemented with sage essential oil significantly increased during storage period. Results showed that there were a significant difference in the peroxide value during the storage period. The lowest PV $(0.541 \mathrm{meqO} / \mathrm{kg})$ was detected at zero time (after preparation), while the highest PV $(6.298 \mathrm{meqO} / \mathrm{kg})$ was detected after four month storage. On the other hand results indicated that the treatment two (4\%) samples was the significantly lowest PV $(2.766$ meqO2 $/ \mathrm{kg})$, while control samples (Co) was the significantly highest PV (4.789 meqO2 $/ \mathrm{kg})$. This could be explained that antioxidant sage extract prevented fish burgers from oxidation. Different studies showed that the addition of rosemary extract or sage extract into fish burgers resulted in lower oxidation in treated samples compared to control groups in terms of peroxide values (Ozogul and Ucar, 2012, Guran et al., 2015, Moosavi-Nasab et al., 2018 and Ali et al., 2019a and b). 
Table (3). Proximate chemical composition of European Anchovy fish burgers supplemented with sage extract before (Zero time) and after 4 month storage (End time) at $-18{ }^{\circ} \mathrm{C}$.

\begin{tabular}{|c|c|c|c|c|c|}
\hline $\begin{array}{l}\text { Storage time } \\
\& \text { treatments }\end{array}$ & Moisture (\%) & Protein (\%) & Lipid (\%) & Ash (\%) & $\begin{array}{c}\text { Nitrogen Free Extract } \\
\text { (NFE) (\%) }\end{array}$ \\
\hline \multicolumn{6}{|l|}{ Zero Time } \\
\hline Control (0\%) & $73.26 \pm 0.012 a$ & $18.34 \pm 0.015 a$ & $3.52 \pm 0.010 a$ & $1.17 \pm 0.010 c$ & $3.71 \pm 0.12$ \\
\hline $2 \%$ & $73.12 \pm 0.018 a$ & $18.38 \pm 0.012 a$ & $3.50 \pm 0.012 a$ & $1.18 \pm 0.012 c$ & $3.82 \pm 0.14$ \\
\hline $4 \%$ & $73.24 \pm 0.014 a$ & $18.36 \pm 0.018 a$ & $3.52 \pm 0.014 a$ & $1.19 \pm 0.011 c$ & $3.69 \pm 0.11$ \\
\hline $6 \%$ & $73.29 \pm 0.022 a$ & $18.84 \pm 0.018 a$ & $3.62 \pm 0.014 a$ & $1.18 \pm 0.012 c$ & $3.07 \pm 0.11$ \\
\hline \multicolumn{6}{|l|}{$\begin{array}{c}\text { End Time } \\
\text { (After } 4 \text { month) }\end{array}$} \\
\hline Control (0\%) & $70.45 \pm 0.015 c$ & $16.44 \pm 0.018 c$ & $2.18 \pm 0.021 b$ & $4.37 \pm 0.014 a$ & $6.56 \pm 0.31$ \\
\hline $2 \%$ & $70.75 \pm 0.012 c$ & $16.48 \pm 0.016 c$ & $2.48 \pm 0.034 b$ & $4.39 \pm 0.012 a$ & $4.73 \pm 0.23$ \\
\hline $4 \%$ & $70.65 \pm 0.016 c$ & $16.74 \pm 0.020 c$ & $2.65 \pm 0.048 b c$ & $4.35 \pm 0.011 a$ & $5.61 \pm 0.21$ \\
\hline $6 \%$ & $71.15 \pm 0.020 c$ & $16.94 \pm 0.022 c$ & $2.98 \pm 0.040 c$ & $4.32 \pm 0.014 a$ & $4.61 \pm 0.14$ \\
\hline
\end{tabular}


Table (4). Peroxide value PV (meq/kg) of European Anchovy fish burgers supplemented with sage essential oil during 4 month storage at $18^{\circ} \mathrm{C}$.

\begin{tabular}{ccccccc}
\hline \multirow{2}{*}{ Treatment } & \multicolumn{5}{c}{ Storage periods (month) } & \multirow{2}{*}{ Mean } \\
\cline { 2 - 6 } & $\mathbf{0}$ & $\mathbf{1}$ & $\mathbf{2}$ & $\mathbf{3}$ & $\mathbf{4}$ & \\
\hline Control (0\%) & $0.557 \pm 0.006$ & $0.960 \pm 0.010$ & $5.840 \pm 0.010$ & $7.500 \pm 0.100$ & $9.090 \pm 0.010$ & $4.789^{\mathrm{a}}$ \\
$\mathbf{2 \%}$ & $0.480 \pm 0.010$ & $0.900 \pm 0.010$ & $3.150 \pm 0.010$ & $4.500 \pm 0.100$ & $4.800 \pm 0.100$ & $2.766^{\mathrm{d}}$ \\
$\mathbf{4 \%}$ & $0.510 \pm 0.010$ & $0.930 \pm 0.010$ & $3.050 \pm 0.010$ & $5.500 \pm 0.100$ & $6.000 \pm 0.100$ & $3.198^{\mathrm{b}}$ \\
$\mathbf{6 \%}$ & $0.620 \pm 0.010$ & $0.950 \pm 0.010$ & $4.040 \pm 0.010$ & $4.900 \pm 0.100$ & $5.300 \pm 0.100$ & $3.162^{\mathrm{c}}$ \\
\hline Mean & $0.541^{\mathrm{e}}$ & $0.935^{\mathrm{d}}$ & $4.020^{\mathrm{c}}$ & $5.600^{\mathrm{b}}$ & $6.298^{\mathrm{a}}$ & \\
\hline
\end{tabular}

\section{Free Fatty Acid (FFA)}

Free fatty acids content has been used to establish the grade of deterioration. Lipids (glycerol and fatty acids esters) present in the fish muscle undergo hydrolysis, resulting in the release of free fatty acids. Due to lipid hydrolysis, FFA accumulates in the tissue during frozen storage (Ali et al., 2019b). Free fatty acids were measured in extracted oil from European anchovy fish burger samples stored at temperatures $-18{ }^{\circ} \mathrm{C}$ for four month (Table 5). Free fatty acids values as oleic acid of control fish burger and all the samples supplemented with sage essential oil significantly increased during storage period. Results indicated that the Free Fatty Acids (FFA) was increased significantly through the storage period with minimum number (1.218) at zero time (after preparation), while the maximum number was (4.283) at the fourth month (End time). On the other hand, results showed that there were a significant difference between the four treatments with different sage essential oil levels. The lowest FFA (2.432) was detected at $(6 \%)$, while the highest FFA (2.797) was detected at control treatment. Free fatty acids of fish burger samples during storage was found to be in parallel to the studies of Vanitha et al. (2015) and Ali et al. (2019b). A similar trend was also observed by the Yerlikaya et al. (2005) during the refrigerated studies of fish patties. These changes have been attributed to enzymic reactions which take place at a rate governed by the temperature of frozen storage. Tokur et al. (2004) published that the FFAs were a result of enzymatic decomposition of lipid during chilled and frozen storage of fish products.

Table (5). Free Fatty Acids FFA (mg/100g) of European Anchovy fish burgers supplemented with sage extract during 4 month storage at $-18{ }^{\circ} \mathrm{C}$.

\begin{tabular}{ccccccc}
\hline \multirow{2}{*}{ Treatment } & \multicolumn{6}{c}{ Storage periods (month) } \\
\cline { 2 - 6 } & $\mathbf{0}$ & $\mathbf{1}$ & $\mathbf{2}$ & $\mathbf{3}$ & $\mathbf{4}$ & \\
\hline Control & $1.140 \pm 0.010$ & $2.510 \pm 0.010$ & $2.980 \pm 0.010$ & $3.157 \pm 1.155$ & $4.200 \pm 0.010$ & $2.797^{\mathrm{a}}$ \\
\hline $\mathbf{2 \%}$ & $1.320 \pm 0.010$ & $2.130 \pm 0.010$ & $2.410 \pm 0.010$ & $2.960 \pm 0.010$ & $4.320 \pm 0.010$ & $2.628^{\mathrm{b}}$ \\
$\mathbf{4 \%}$ & $1.250 \pm 0.010$ & $2.45 \pm 0.010$ & $2.390 \pm 0.010$ & $2.810 \pm 0.010$ & $4.390 \pm 0.010$ & $2.658^{\mathrm{ab}}$ \\
$\mathbf{6 \%}$ & $1.160 \pm 0.010$ & $1.970 \pm 0.010$ & $2.180 \pm 0.010$ & $2.630 \pm 0.010$ & $4.220 \pm 0.010$ & $2.432^{\mathrm{ab}}$ \\
\hline Mean & $1.218^{\mathrm{e}}$ & $2.265^{\mathrm{d}}$ & $2.490^{\mathrm{C}}$ & $2.889^{\mathrm{b}}$ & $4.283^{\mathrm{a}}$ & \\
\hline
\end{tabular}




\section{Fatty acid composition}

Data in Table (6) showed the fatty acids composition of oil extracted from control and supplemented European anchovy fish burgers with sage extract ( $2 \%$ as $\mathrm{T} 1,4 \%$ as T2 and $6 \%$ as T3) before and after 4 month storage at $-18{ }^{\circ} \mathrm{C}$. A total of 14 fatty acids were determined by using GC-MS. In general, results of fatty acid composition showed that saturated fatty acids (SFAs) in fresh fish burgers samples were in the highest levels ranged from 37.48 to $37.90 \%$, followed by polyunsaturated fatty acids (PUFAs) ranged from 31.31 to 33.51 and monounsaturated fatty acids (MUFAs) ranged from 29.01 to $31.01 \%$. The obtained results are in agreement with these reported by Naseri et al. (2010) who found that PUFAs of raw silver carp oil recorded about $35 \%$, SFAs were $34 \%$ and MUFAs were $31 \%$.

Regarding to SFAs, palmitic acid $\left(\mathrm{C}_{16: 0}\right)$, stearic acid $\left(\mathrm{C}_{18: 0}\right)$, and myristic acid $\left(\mathrm{C}_{14: 0}\right)$ were the major fatty acids among the SFAs of European anchovy fish burgers and lauric acid $\left(\mathrm{C}_{12: 0}\right)$ was in minimum in value (Table 6$)$. Differences were observed between treatments among the total SFAs after 4 month storage at -18 ${ }^{\circ} \mathrm{C}$. Total SFAs increased more in control than supplemented burgers with sage essential oil $(2 \%, 4 \%$ and $6 \%)$.

The increase in SFAs during the freezing for $180 \mathrm{~d}$ was reported by Barrero and Bello (2001) in sardine meat (Sardinella aurita), which was similar to the results obtained in this study. This performance was due to the degradation of PUFAs, which generated low molecular weight compounds and possibly short chain FAs. The results from this study were in agreement to those reported by Pirestani et al. (2010) in several species of fishes from South Caspian, when fillets were stored at $-8^{\circ} \mathrm{C}$ during 6 months. Saldanha et al. (2008) found that Brazilian sardine (Sardinella brasiliensis) presented the same FAs performance when was frozen at $-8^{\circ} \mathrm{C}$ for 120 days. Regarding to MUFAs, oleic acid $\left(\mathrm{C}_{18: 1}\right)$ was in the maximum value of oil extracted from fresh anchovy fish burgers $(23.24-24.88 \%$ of total fatty acids) as compared to other MUFAs. Total MUFAs increased more in supplemented burger samples than control after four month storage at $-18{ }^{\circ} \mathrm{C}$. European anchovy fish generally contains a high level of oleic acid and a low level of linoleic acid (Csengeri, 1996).

Regarding to polyunsaturated fatty acids PUFAs, total PUFA decreased more in control than supplemented burgers with sage essential oil $(r \%, 4 \%$ and $6 \%$ ) after 4 month storage at $-18{ }^{\circ} \mathrm{C}$. Fresh European Anchovy fish burgers contained high concentrations of $n-3$, which included docosahexaenoic acid (DHA) presenting the highest concentration $(16.62-19.71 \%)$ of PUFA followed by eicosapentaenoic acid (EPA) presenting $(7.38-7.43 \%)$ of PUFA. When fish burgers were frozen, $n-3$ concentration decreased. At the end of the trial $(4$ month of frozen storage), DHA and EPA decreased more in control samples from $16.62 \%$ and $7.43 \%$ at zero time to $9.65 \%$ and $4.41 \%$, respectively after 4 month storage than supplemented sample T3 from $19.71 \%$ and $7.38 \%$ at zero time to $14.80 \%$ and $5.73 \%$ after 4 month storage. During storage, fish are capable of converting PUFA 
to the shorter chain fatty acids (Aubourg, 1999, Du et al., 2008 and Murray et al., 2014). For this reason, saturated fatty acids levels were increased after four month storage at $-18{ }^{\circ} \mathrm{C}$. These results were in agreement with results of Yildiz et al. (2008).

Polyunsaturated fatty acids reduction was due to oxidative and hydrolytic reactions that occurred during the storage. Yi-Chen et al. (2008) showed that long hydrocarbon chains and high unsaturation of PUFA made them more susceptible to hydrolytic reactions than the SFA. This susceptibility to these reactions could be influenced by the high content of DHA found in the fresh fish. Because of this PUFAs are the main FAs involved in the processes of oxidation (Chen et al., 2007).

The effects of storage time on the lipid quality of anchovy fish burgers were examined in this study. The PUFA/SFA ratio is used to estimate the nutritional quality of lipids and their influence on coronary heart disease (Liu et al., 2013). Health guidelines recommend a ratio $>0.436$ (FAO/WHO, 1994). In the present study, PUFA/SFA ratio was of 0.831 for fresh control burger samples, which was higher than the minimum suggested $(0.450)$ for a human healthy diet (HMSO, 1994). This ratio decreased to 0.364 after four month storage at $4{ }^{\circ} \mathrm{C}$, which was lower than the minimum suggested for a human healthy diet. On the other hand, this ratio decreased in supplemented burger sample (6\%) from 0.894 to 0.606 after four month storage at $-18{ }^{\circ} \mathrm{C}$, which both were higher than the minimum suggested for a human healthy diet.

Similar results in rainbow trout were reported by Danabas (2011). During the frozen storage, PUFA/SFA ratio decreased significantly $(P \leq 0.05)$ due to loss of PUFAs, and as expected SFAs increased. Similar to these results, Pérez-Mateos et al. (2004) had observed that this ratio decreased during $90 \mathrm{~d}$ storage of surimi fish at $-22.3^{\circ} \mathrm{C}$.It has been suggested that EPA+DHA/C16 ratio (polyene index $\mathrm{PI}$ ) is a good index for a determination of lipid oxidation (Jeong et al., 1990). PI is an effective parameter for measuring the oxidative rancidity of anchovy fish burgers. During frozen storage, the index declined, while atherogenic (AI) and thrombogenic (IT) indexes increased.

Atherogenic and thrombogenic indexes could be used as a tool in order to compare how healthy was the lipid fraction of different foods (Rossano et al., 2005). The results of this study could be attributed to DHA being the most reduced PUFA, and because it was found in high amounts in the fish burger samples.

Results showed that during the frozen storage, polyene index decreased because the relationship among the PUFA and palmitic acid decreased due to a reduction of DHA and EPA, and an increase in palmitic acid concentration. The change in $\mathrm{PI}$ value is mainly due to the degradation of DHA and EPA.

In this study, the decrease of PI resulted in an increase in primary and secondary oxidation products (POV and TBARS). 
Table (6). Fatty Acid profile (\%) of extracted oil from European Anchovy fish burgers samples at Zero time and after 4 month storage (End time) at $-18{ }^{\circ} \mathrm{C}$

\begin{tabular}{|c|c|c|c|c|}
\hline \multirow{2}{*}{ Fatty acids } & \multicolumn{4}{|c|}{ Treatments, sage essential oil } \\
\hline & Control (0\%) & $2 \%$ & $4 \%$ & $6 \%$ \\
\hline \multicolumn{5}{|l|}{ Lauric $\mathbf{C}_{12: 0}$} \\
\hline Zero time & 0.73 & 0.84 & 0.81 & 0.42 \\
\hline End time & 1.11 & 0.95 & 1.23 & 0.31 \\
\hline \multicolumn{5}{|c|}{ Myristic $\mathrm{C}_{14: 0}$} \\
\hline Zero time & 6.38 & 6.66 & 6.57 & 6.73 \\
\hline End time & 7.38 & 6.32 & 6.57 & 7.03 \\
\hline \multicolumn{5}{|l|}{ Palmitic $C_{16: 0}$} \\
\hline Zero time & 21.90 & 21.43 & 21.62 & 21.72 \\
\hline End time & 24.32 & 23.22 & 21.92 & 21.55 \\
\hline \multicolumn{5}{|l|}{ Stearic $C_{18: 0}$} \\
\hline Zero time & 8.67 & 8.97 & 8.73 & 8.61 \\
\hline End time & 13.34 & 11.63 & 10.57 & 9.12 \\
\hline \multicolumn{5}{|l|}{ Total SFA } \\
\hline Zero time & 37.68 & 37.90 & 37.73 & 37.48 \\
\hline End time & 46.15 & 42.12 & 40.29 & 38.01 \\
\hline \multicolumn{5}{|c|}{ Palmitoleic $\mathbf{C}_{16: 1}$} \\
\hline Zero time & 4.77 & 4.91 & 4.98 & 4.01 \\
\hline End time & 3.63 & 4.32 & 4.79 & 4.89 \\
\hline \multicolumn{5}{|l|}{ Oleic $C_{18: 1}$} \\
\hline Zero time & 24.88 & 23.92 & 23.24 & 23.51 \\
\hline End time & 32.42 & 33.23 & 33.76 & 32.49 \\
\hline \multicolumn{5}{|c|}{ 9n Eicosaenoic $C_{20: 1}$} \\
\hline Zero time & 1.36 & 1.41 & 1.42 & 1.49 \\
\hline End time & ND & 0.32 & 0.63 & 0.57 \\
\hline \multicolumn{5}{|l|}{ Total MUFA } \\
\hline Zero time & 31.01 & 30.24 & 29.64 & 29.01 \\
\hline End time & 36.05 & 37.87 & 39.18 & 38.95 \\
\hline \multicolumn{5}{|c|}{ Linoleic $\mathbf{C}_{18: 2} \mathrm{n} 6$} \\
\hline Zero time & 3.58 & 3.02 & 3.15 & 3.01 \\
\hline End time & 1.53 & 1.8 & 3.01 & 1.13 \\
\hline \multicolumn{5}{|c|}{ Linolenic $C_{18: 3} \mathrm{n} 3$} \\
\hline Zero time & 0.73 & 0.71 & 0.73 & 0.76 \\
\hline End time & 0.20 & 0.33 & 0.44 & 0.68 \\
\hline \multicolumn{5}{|c|}{ Arachidonic $\mathbf{C}_{20: 4} \mathrm{n} 6$} \\
\hline Zero time & 0.59 & 0.52 & 0.55 & 0.56 \\
\hline End time & ND & ND & ND & ND \\
\hline
\end{tabular}


Continue Table (5)

\begin{tabular}{|c|c|c|c|c|}
\hline EPA C $_{20: 5}$ n3 & & & & \\
\hline Zero time & 7.43 & 7.40 & 7.43 & 7.38 \\
\hline End time & 4.41 & 5.15 & 5.1 & 5.73 \\
\hline \multicolumn{5}{|l|}{ DPA C $_{22: 5}$ n3 } \\
\hline Zero time & 2.36 & 3.11 & 2.31 & 2.09 \\
\hline End time & 1.01 & 1.02 & 0.90 & 0.70 \\
\hline \multicolumn{5}{|l|}{$\mathrm{DHA} \mathrm{C}_{22: 6} \mathrm{n3}$} \\
\hline Zero time & 16.62 & 17.10 & 18.46 & 19.71 \\
\hline End time & 9.65 & 11.71 & 13.08 & 14.80 \\
\hline \multicolumn{5}{|l|}{ Total PUFA } \\
\hline Zero time & 31.31 & 31.86 & 32.63 & 33.51 \\
\hline End time & 16.80 & 20.01 & 22.53 & 23.04 \\
\hline \multicolumn{5}{|l|}{ PUFA SFA } \\
\hline Zero time & 0.831 & 0.841 & 0.865 & 0.894 \\
\hline End time & 0.364 & 0.475 & 0.559 & 0.606 \\
\hline \multicolumn{5}{|l|}{ PI } \\
\hline Zero time & 1.100 & 1.143 & 1.198 & 1.247 \\
\hline End time & 0.578 & 0.726 & 0.829 & 0.940 \\
\hline \multicolumn{5}{|l|}{$\mathrm{Al}$} \\
\hline Zero time & 0.773 & 0.788 & 0.782 & 0.784 \\
\hline End time & 1.040 & 0.854 & 0.801 & 0.799 \\
\hline \multicolumn{5}{|l|}{ IT } \\
\hline Zero time & 0.350 & 0.337 & 0.332 & 0.324 \\
\hline End time & 0.770 & 0.487 & 0.453 & 0.372 \\
\hline
\end{tabular}

\section{Sensory evaluation}

The results of sensory evaluation are one of the most important quality criteria used for determination of shelf life of seafood. The changes of sensory properties (colour, odour, taste, texture and overall acceptability) of fried anchovy fish burgers supplemented individually with $2.0 \%, 4.0 \%$ and $6.0 \%$ sage essential oil and untreated (control) during freezing storage at $-18 \pm 1^{\circ} \mathrm{C}$ were recorded in Table (7).The results of the sensory evaluation (colour, odour, test, texture and overall acceptability) of anchovy fish burgers are presented in Table 7. According to the statistical analysis, there were no significant differences $(P>0.05)$ in colour, odour, taste and texture between all fish burger treatments at zero time before storage. Significant differences $(P<0.05)$ were observed between the control and treated samples after storage at $-18 \pm 1^{\circ} \mathrm{C}$. $(4 \%)$ and $(6 \%)$ were mostly preferred by the panelists. The use of sage extract improved the sensory quality of fish burgers. Similar results have been reported in the other fish products treated with rosemary and sage extracts (Corbo et al. 2009, Mahmoudzadeh et al., 2010 and Uçak et al. 2011).

In the present study, it was demonstrated that the addition of sage essential oils into anchovy fish burgers did not affect certain sensory properties as colour, odour, taste, and texture before freezing storage but had an effect on the sensory 
of the product after 4 month freezing storage. However, the fish burgers used in the present study are a very complex food containing spices such as cumin, white pepper, onions etc. Presumably, the negative effect of essential oils on the sensory attributes of the fish burgers may be masked by the ingredients and spices used in the production of fish burgers. The use of higher concentrations than we used in the present study may result in a further increase of the shelf life of fish burgers, but high essential oils concentrations would probably impart unpleasant sensory effects (strong odour and flavour, etc.) on the quality of fish burgers. Natural preservatives such as essential oils can be used as a safe method for storage of fish burgers. According to Orak and Kayisoglu (2008) the decrease in the values of sensory analyses was faster than chemical changes during frozen storage.

Oxidation of unsaturated fatty acids could produce ketones, aldehydes, alcohols, hydrocarbons, acids, and epoxides that interact with proteins thereby forming off-color during frozen storage (Thanonkaew et al., 2006). Also the formation of aldehydes and ketones can cause denaturation of myofibrillar proteins and rancid off-flavors that affect the sensory attributes even in a little amount (Tokur et al., 2006). Even through the added EOs delayed oxidation and extending the shelf-life, their antioxidant activity reduced during storage by increase significantly $(p<0.05)$ differences in all individual tested samples during the end of storage periods.The present study showed that a treatment with $2-4 \%$ sage essential oil/kg fish burger could effectively delay chemical deterioration, maintain or improve sensory attributes, and extend the shelf life of fish burger samples for 4 month during freezing storage. However, further studies are needed with regard to the preservation of fish burgers using natural preservatives, including essential oils, in view of increasing the consumer demand for preservative-free seafood.

Table (7). Sensory analyses of fish burgers before and after 4 month storage at $-18 \pm 1^{\circ} \mathrm{C}$

\begin{tabular}{|c|c|c|c|c|}
\hline \multirow{2}{*}{ Sensory parameter } & \multicolumn{4}{|c|}{ Treatments, sage essential oils } \\
\hline & Control (0\%) & $2 \%$ & $4 \%$ & $6 \%$ \\
\hline \multicolumn{5}{|l|}{ Colour } \\
\hline Zero time & $9.40^{\mathrm{a}}$ & $9.60^{\mathrm{a}}$ & $9.70^{a}$ & $9.70^{a}$ \\
\hline End time & $8.40^{\mathrm{b}}$ & $7.20^{\mathrm{C}}$ & $6.60^{\mathrm{d}}$ & $6.50^{\mathrm{d}}$ \\
\hline \multicolumn{5}{|l|}{ Odour } \\
\hline Zero time & $8.60^{\mathrm{a}}$ & $9.20^{\mathrm{a}}$ & $9.050^{a}$ & $8.60^{a}$ \\
\hline End time & $5.00^{b}$ & $6.20^{c}$ & $7.00^{\mathrm{d}}$ & $7.20^{\mathrm{d}}$ \\
\hline \multicolumn{5}{|l|}{ Taste } \\
\hline Zero time & $9.60^{a}$ & $9.60^{a}$ & $9.30^{\mathrm{a}}$ & $9.40^{\mathrm{a}}$ \\
\hline End time & $4.60^{b}$ & $7.00^{c}$ & $7.80^{\mathrm{d}}$ & $7.60^{d}$ \\
\hline \multicolumn{5}{|l|}{ Texture } \\
\hline Zero time & $9.20^{\mathrm{a}}$ & $9.40^{\mathrm{a}}$ & $9.40^{a}$ & $9.70^{a}$ \\
\hline End time & $4.60^{\mathrm{b}}$ & $7.20^{\mathrm{c}}$ & $7.40^{\mathrm{C}}$ & $7.40^{\mathrm{C}}$ \\
\hline \multicolumn{5}{|l|}{ Overall acceptability } \\
\hline Zero time & $9.20^{\mathrm{a}}$ & $9.46^{\mathrm{a}}$ & $9.34^{\mathrm{a}}$ & $9.36^{\mathrm{a}}$ \\
\hline End time & $4.60^{b}$ & $6.90^{\mathrm{C}}$ & $7.20^{d}$ & $7.18^{d}$ \\
\hline
\end{tabular}




\section{CONCLUSION}

The obtained results in this study showed the utilization of unaccepted cheap small anchovy fish from consumers in its fresh form in the production of good fish burgers products high safely, having good quality and better acceptability with lowering the costs. The tested essential oils extracted from sage leaves had high effectiveness as an antioxidant and should be utilized for extending the shelflife and enhancing quality attributes of anchovy fish burger during frozen storage at $-18 \pm 1^{\circ} \mathrm{C}$. The chemical and the sensory analysis revealed that prepared anchovy fish burgers significantly affected by frozen storage for 4 months at $-18^{\circ} \mathrm{C}$. Anchovy fish burgers supplemented with $4-6 \%$ sage extract were of high quality and acceptance even after the storage period is over.

\section{REFERENCES}

Abdeldaiem, M.H., Ali, H. G. and Ramadan, M.F. (2017). Impact of different essential oils on the characteristics of refrigerated carp (Cyprinus carpio) fish fingers. Food Measure, 11, 1412-1420.

Abo-Taleb, M. (1997). Studies on the utilization of Carp fish in some fishery products. Ph.D. Thesis, Fac of Agric, Ain Shams University Cairo, Egypt.

Abuajah, C.I., Ogbonna, A.C. and Osuji, C.M. (2014). Functional components and medicinal properties of food: a review. Journal of Food Science and Technology, 52, 2522-2529.

Al-Bulushi, I.M., Kasapis, S., Al-Oufi, H. and Al-Mamari, S. (2005). Evaluating the quality and storage stability of fish burgers during frozen storage. Fisheries Science, 71, 648-654.

Ali, M., Imran, M., Nadeem, M., Khan, M., Sohaib, M., Suleria, H. and Bashir, R. (2019a). Oxidative stability and Sensoric acceptability of functional fish meat product supplemented with plant-based polyphenolic optimal extracts. Lipids in Health and Disease, 18, 1-16.

Ali, H., Mansour, E., E-IBedawey, A. and Osheba, A. (2019b). Evaluation of tilapia fish burgers as affected by different replacement levels of mashed pumpkin or mashed potato. Journal of the Saudi Society of Agricultural Sciences, 18, 127-132.

Alizadeh, E., Chapleau, N., De, lamballerie, M. and Le-bail, A. (2007). Effect of different freezing processes on the microstructure of Atlantic salmon (Salmo salar) fillets. Innov. Food Sci. Emerg. Technol., 8, 493-499.

AOAC (2007). Official methods of analysis. ( $20^{\text {th }}$ edn), Association of Analytical Chemists International, Gacthersburg, MD, USA.

Atitallah, A., Barkallah, M., Hentati, F., Dammak, M., Fendri, I., Attia, H., Michaud, P. and Abdelkafi, S. (2019). Physicochemical, textural, antioxidant and sensory characteristics of microalgae-fortified canned fish burgers prepared from minced flesh of common barbel (Barbus barbus). Food Bioscience, 30, 1-9. 
Aubourg, S. P. and Medina, I. (1999). Influence of storage time and temperature on lipid deterioration during cod (Gadusmorhua) and haddock (Melano grammusae glefinus) frozen storage. J of the Sci. of Food and Agric., 70,1943-1948.

Babović, N., Žizović, I., Saicć, S., Ivanović, J. and Petrović, S. (2010). Oxidative stabilisation of sunflower oilby antioxidant fractions from selected Lamiaceaeherbs. Chem. Ind. Chem. Eng. Q.16, 287-293.

Barrero $\mathrm{M}$ and Bello R. (2001). Efecto de la congelación $-40^{\circ} \mathrm{C}$ en los ácidos grasos de la pulpa de sardina (Sardinella aurita) lavada con una solución de bicarbonato de sodio al 0.5\%. Revista Científica. FCV-LUZ., 9, 230-239.

Ben Khedher, M., Ben Khedher, S., Chaieb, I., Tounsi, S. and Hammami, M. (2017). Chemical composition of Salvia officinalis essential oil from Tunsia. EXCLI Journal 2017;16:160-173

Chen, Y.C., Nguyen, J., Semmens, K., Beamer, S. and Jaczynski, J. (2007). Physicochemical changes in $\omega-3$ enhanced farmed rainbow trout (Oncorhynchus mykiss) muscle during refrigerated storage. Food Chem., 104, 1143-1152.

Corbo, M.R., Bevilacqua, A., Campaniello, D., Amato, D. and Speranza, B. (2009). Prolonging microbial shelf-life of foods through the use of natural compounds and non-thermal approaches-A review. Int. J. Food Sci. Technol., 44, 223-241.

Csengeri, I. (1996). Dietary effects on fatty acid metabolism of common carp. Arch. Anim. Nutr., 49,73-92.

Danabas D. (2011). Fatty acids profiles of rainbow trout (Oncorhynchus mykiss Walbaum 1972), fed with zeolite (Clinoptilolite). J Anim Plant Sci., 21, 561565.

Dolea, D., Rizo, A., Fuentes, A., Barat, J. and Ferna'ndez-Segovia, I. (2018). Effect of thyme and oregano essential oils on the shelf life of salmon and seaweed burgers. Food Science and Technology International, 1-10.

Du, Z.Y., Clouet, P., Huang, L.M., Degrace, P., Zheng, W.H., He, J.G., Tian, L.X. and Liu, Y.J. (2008). Utilization of different dietary lipid sources at high level in herbivorous grass carp (Ctenopharyngodon idella): mechanism related to hepatic fatty acid oxidation. Aquaculture Nutrition, 14, 77-92.

Edwards, S. and Kaewpaitoon, M. (1981). "Fish Farming with Livestock Manure'. Paper presented at a seminar on Maximum Livestock Production from Minimum Land, jointly organized by the Department of Animal Science, BAU, NYRDP-DANIDA, Bangladesh Agricultural University, Mymensingh, 25 February, 1981.

El-Lahamy, A.A., Khalil, K.I., El-Sherif, S.A. and Mahmud, A.A. (2019). Effect of Frozen Storage on the Chemical Composition of Sand Smelt (Atherina hepsetus) Fish Burger and Finger. Journal of Fisheries Sciences, 13, 7-13.

Estevez, M., Ramírez, R., Ventanas, S. and Cava, R. (2007). Sage and rosemary essential oils versus $\mathrm{BHT}$ for the inhibition of lipid oxidative reactions in liver pate. LWT - Food Science and Technology, 40, 58- 65.

FAO/WHO (1994). Fats and oils in human nutrition: Report of a joint expert consultation. Rome, Italy. 
Fasseas, M. K., Mountzouris, K. C., Tarantilis, P. A., Polissiou, M. and Zervas, G. (2008). Antioxidant activity in meat treated with oregano and sage essential oils. Food Chemistry, 106, 1188-1194.

Fogaça, F. H. S., and Sant'ana, L. S. (2009). Lipid oxidation in fishes: Action mechanism and prevention. Archives of Veterinary Science, 14(1517I), 117127.

Folch, J., Lees, M. and Bloune, S.G. (1957). A simple method for their isolation and purification of total lipids from animal tissues. Biological Chemistry, 266, 497-509.

Gandotra, R., Koul, M., Gupta, S. and Sharma, S. (2012). Change In Proximate Composition And Microbial Count By Low Temperature Preservation In Fish Muscle of Labeo Rohita (Ham-Buch). IOSR Journal of Pharmacy and Biological Sciences (IOSRJPBS) 2, 13-17.

Gomma, R. A. M. (2005). Studies on producing sausage from some fish types. M.Sc. Thesis, Fac. of Agric. Al-Azher Uni., Egypt.

Güner, S., Dinçer, B., Alemdağ, N., Çolak, A. and Tüfekçi, M. (1998). Proximate composition and selected mineral content of commercially important fish species from the Black Sea. Journal of the Science of Food and Agriculture, 78, 337-342.

Guran , H., Oksuztepe, G., Coban, O. and Incili, G. (2015). Influence of Different Essential Oils on Refrigerated Fish Patties Produced from Bonito Fish (Sarda sarda Bloch, 1793). Czech J. Food Sci., 33, 37-44.

Hall, G.M. (2011). Freezing and chilling of fish and fish products. Blackwell Publishing Ltd, pp: 77-97.

Hassab Alla, A.Z., Mohamed, G.F. and AbdEIMageed, M.A. (2009). Frozen cooked catfish burger: effect of different cooking methods and storage on its quality. Global Veterinaria, 3, 216-226.

Hassoun, A. and Çoban, O. (2017). Essential oils for antimicrobial and antioxidant applications in fish and other seafood products. Trends in Food Science and Technology, 68, $26-36$.

HMSO (1994). Nutritional aspects of cardiovascular disease. Report on Health and Social Subject No. 46. London, England. Department of Health. Her Majesty`s Stationery Office.

Husein, Y., Secci, G., Dinnella, C., Parisi, G., Monteleone, E. and Zanoni, B. (2019). Enhanced utilisation of nonmarketable fish: physical, nutritional and sensory properties of 'clean label' fish burgers. International Journal of Food Science and Technology, 54, 593-601.

Ibrahim, S.M. and El-Sherif, S.A. (2008). Effect of some plant extracts on quality aspects of frozen Tilapia (Oreachromis niloticus L.) Global Veterinaria 2, 6266.

Ihm, C.W., Kim, J.S., Joo, D.S. and Lee, H.E. (1992a). Processing and quality stability of precooked frozen fish foods: (I) Processing of sardine burger. Hanquk Nonghwakak Hoechi. Journal of Korean Agriculturist Chemical Society, 34, 254-259.

Ihm, C.W., Kim, J.S., Joo, D.S. and Lee, H.E. (1992b). Processing and quality stability of precooked frozen fish foods: (II) Processing of sardine burger. 
Hanquk Nonghwakak Hoechi. Journal of Korean Agriculturist Chemical Society, 35, 260-264.

Jeong, B. Y., Oshima, T., Koizumi, C. and Kanou, Y. (1990). Lipid Deterioration and Its Inhibition of Japanese Oyster (Crasostrea gigas) during Frozen Storage. Nippon Suisan Gakkaishi, 56, 2083-2091.

Jessen, F., Nielsen, J. and Larsen, E. (2014). Chilling and freezing of fish. Seafood processing, pp: 33-59.

Khidhir, Z.K., Murad, H.O. and Arif, E.D. (2013). Qualitative assessment of imported frozen fish fillets in Sulaimani markets. Iraqi J Vet Sci., 27, 49-55.

Kirk, R.S. and Sawyer, R. (1991). Pearson's composition and Analysis of Foods, $9^{\text {th }}$ edition, Addison Wesley Longman Ltd., England. 9-29, 608-640.

Kurtcan Ü. and Gönül M. (1987). Scoring method of sensory evaluation of foods. Ege University Journal of Faculty Engineering, 5, 137-146

Lazos, S.E. (1996). Utilization of Freshwater Bream for Canned Fish Ball Manufacture. Journal of Aquatic Food Product Technology, 5, 47-64.

Liu, K., Ge, S.Y., Luo, H.L., Yue, D.B. and Yan, L.Y. (2013). Effects of dietary vitamin $E$ on muscle vitamin $E$ and fatty acid content in Aohan fine-wool sheep. J. Anim. Sci. Biotechnol., 4, 21- 29.

Ludy, F.E., Barford, R.A. and Riemenschneider, R.W. (1960). Direct conversion of lipid components to their fatty acid methyl esters. Journal of the American Oil Chemists' Society, Chicago, 37, 447-451.

Mahmoudzadeh, M., Motallebi, A., Hosseini, H., Khaksar, R., Ahmadi, H., Jenab, E., Shahraz, F. and Kamran, M. (2010). Quality changes of fish burgers prepared from deep flounder (Pseudorhombus elevatus Ogilby, $1912)$ with and without coating during frozen storage $\left(-18^{\circ} \mathrm{C}\right)$. International Journal of Food Science and Technology, 45, 374-379.

Mariutti, L. R. B., Nogueira, G. C. and Bragagnolo, N. (2011). Lipid and cholesterol oxidation in chicken meat are inhibited by sage but not by garlic. Journal of Food Science, 76, C909-C915.

Mariutti, L. R. B., Orlien, V., Bragagnolo, N. and Skibsted, L. H. (2008). Effect of sage and garlic on lipid oxidation in high-pressure processed chicken meat. European Food Research and Technology, 227, 337-344.

Mattje, L.G., Tormen, L., Bombardelli, M. C., Corazza, M.L. and Bainy, E.M. (2019). Ginger essential oil and supercritical extract as natural antioxidants in tilapia fish burger. J. Food Process. Preserv., 43, 1-8.

Merched, A.J., Ko, K., Gotlinger, K.H., Serhan, C.N. and Chan, L. (2008). Atherosclerosis: evidence for impairment of resolution of vascular inflammation governed by specific lipid mediators. FASEB Journal: Official Publication of the Federation of American Societies for Experimental Biology, 22, 3595-3606.

Mexis, S.F., Chouliara, E. and Kontominas, M.G. (2009). Combined effect of an oxygen absorber and oregano essential oil on shelf life extension of rainbow trout fillets stored at $4^{\circ} \mathrm{C}$. Food Microbiol., 26, 598-605.

Mizi, L., Cofrades, S., Bou, R., Pintado, T., López-Caballero, M.E., Zaidi, F. and Jiménez-Colmenero, F. (2019). Antimicrobial and antioxidant effects of combined high pressure processing and sage in beef burgers during 
prolonged chilled storage. Innovative Food Science and Emerging Technologies, 51, 32-40.

Moosavi-Nasab, Najme, M. and Oliyaei, N. (2018). Physicochemical evaluation of sausages prepared by lantern fish (Benthosema pterotum) protein isolate Food Sci Nutr., 6, 617-626.

Murray, D.S., Hager, H., Tocher, D.R. and Kainz, M.J. (2014). Effect of partial replacement of dietary fish meal and oil by pumpkin kernel cake and rapeseed oil on fatty acid composition and metabolism in Arctic charr (Salvelinus alpinus). Aquaculture, 431, 85-91.

Nakatani, N. (1994). Antioxidative and antimicrobial constituents of herbs and spices, in: spices, herbs and edible fungi. Elsevier Science, New York, pp: 251-271.

Naseri, M., Rezaei, M., Moieni, S., Hosseni, H. and Eskandari, S. (2010). Effect of different precooking methods on chemical composition and lipid damage of silver carp (Hypophthalmichthys molitrix) muscle. Inter. J of Food Sci. and Tech., 45:1973-1979.

Obiero, K., Meulenbroek, P., Drexler, S., Dagne, A., Akoll, P., Odong, R., Kaunda-Arara, B. and Waidbacher, H. (2019). The Contribution of Fish to Food and Nutrition Security in Eastern Africa: Emerging Trends and Future Outlooks. Sustainability 2019, 11, 1-15.

Orak, H.H. and Kayisoglu, S. (2008). Quality changes in whole, gutted and filletd three fish species (Gadus euxinus, Mugil cephalus, Engraulis encrasicholus) at frozen storage period $\left(-26^{\circ} \mathrm{C}\right)$. Acta Scientiarum Polonorum Technologia Alimentaria, 7, 15-28.

Ozogul, Y. and Ucar, Y. (2012). The effects of natural extracts on the quality changes of frozen chub mackerel (Scomber japonicus) burgers. Food and Bioprocess Technology, 6, 1550-1560.

Pauly, D. and Froese, R. (2012). Comments on FAO's state of fisheries and aquaculture, SOFIA 2010". Marine Policy, 36, 746-752.

Perez-Mateos, S.M., Byd, L. and Lanier, T. (2004). Stability of omega-3 fatty acids in fortified surimi seafoods during chilled storage. J Agric Food Chem., 52, 7944-7949.

Pirestani, S., Sahari MA and Barzegar M. (2010). Fatty acids changes during frozen storage in several fish species from South Caspian Sea. J Agr Sci Tech., 12, 321-329.

Porte, A. and Godoy, R.L. (2008). Chemical composition of Thymus vulgaris L. (thyme) essential oil from the Rio de Janeiro State (Brazil). Journal of the Serbian Chemical Society, v. 73, n. 3, p. 307-10, 2008.

Qendouci, M., Amenzoui, K., Baali, A., El Qoraychy, I. and Yahyaoui, A. (2018). Diet of anchovy Engraulis encrasicolus (Engraulidae) in Moroccan Atlantic coast. AACL Bioflux, 11, 1388- 1398.

Raeisi, S., Shabanpour, B., Alishahi, A.R., Ojagh, S.M. and Quek, S.Y. (2015). Evaluation of antioxidant and antimicrobial effects of shallot (Allium ascalonicum L.) fruit and ajwain (Trachyspermum ammi (L.) Sprague) seed extracts in semi-fried coated rainbow trout (Oncorhynchus mykiss) fillets for shelf-life extension. Food Science and Technology, 65, 112-121. 
Rossano, R., Caggiano, M.A., Mastrangelo, L., Di Lauro, R., Ungaro, N. and Ettorre, M. (2005). Proteins, fatty acids and nutritional value in the muscle of the fish species Mora moro (Risso, 1810). Mol Nutr Food Res., 49, 926931.

Roomiani, L., Ghaeni, M., Moarref, M., Fallahi, R. and Lakzaie, F. (2019). The effects of Rosmarinus officinalis essential oil on the quality changes and fatty acids of Ctenopharyngodon idella. Iranian Journal of Fisheries Sciences, 18, 95-109.

Said-Al Ahl, H., Hussein, M., Gendy, A. and Tkachenko, K. (2015). Quality of Sage (Salvia officinalis L.) Essential Oil Grown in Egypt. International Journal of Plant Science and Ecology, 1, 119-123.

Saldanha T, Benass MT and Bragagnolo N. (2008). Fatty acid contents evolution and cholesterol oxides formation in Brazilian sardines followed by grilling. Food Sci Tech., 41, 1301-1309.

Saleem, M., A El-Sherif, S., Sharaf, A. and Abo-Zeid, K. (2019). Influence of Essential Oils and Frozen Storage on Quality Parameters of Catfish (Clarias gariepinus) Burgers and Fingers. J Food Process Technol, 10, 1-7.

Sepahvand, R., Delfan, B., Ghanbarzadeh, S., Rashidipour, M., Veiskarami, G. H. and Ghasemian-Yadegari, J. (2014). Chemical composition, antioxidant activity and antibacterial effect of essential oil of the aerial parts of Salvia sclareoides. Asian Pacific Journal of Tropical Medicine, 7, S491-S496.

Singh, G., Marimuthu, P., Murali, H. and Bawa, A. (2005). Antioxidative and antibacterial potentials of essential oils and extracts isolated from various spices materials. J. Food Safety, 25, 130-145.

Shan, B., Cai, Y.Z., Sun, M. and Corke, H. (2005). Antioxidant capacity of 26 spice extracts and characterization of their phenolic constituents. J Agri. and Food Chem., 53, 7749-7759.

Shahin, M. F. S. A., Mahmoud, F. S. A. Kdous and Sanaa, A. Hussein (2016). Production of New Burger from Small Size Shrimp and Carp Fish Meat. Current Science International, 5, 223-230.

Taskaya, L., Hasanhocaoglu, H., Metini, C. and Alparslan, Y. (2018). The effect of lavender (Lavandula stoechas) on the shelf life of a traditional food: hamsi kaygana. Food Sci. Technol, Campinas, 38, 711-718.

Thanonkaew, A., Benjakul, S., Visessanguan, W. and Decker, E.A. (2006). The effect of metal ions on lipid oxidation, color and physicochemical properties of cuttlefish (Sepia pharaonis) subjected to multiple freeze-thaw cycles. Food Chemistry, 95, 591-599.

Tokur, B., Polat, A., Beklevik, G. and Ozkutuk, S. (2004). Changes in the quality of fishburger produced from Tilapia (Oreochromis niloticus) during frozen storage $\left(-18^{\circ} \mathrm{C}\right)$. European Food Research and Technology, 218, 420-423.

Tokur, B., Ozkutuk, S., Atici, E., Ozyurt, G. and Ozyurt, C.E. (2006). Chemical and sensory quality changes of fish fingers, made from mirror carp (Cyprinus carpio L., 1758), during frozen storage $\left(-18^{\circ} \mathrm{C}\right)$. Food Chemistry, 99, 335-341.

Türkiye İstatistik Kurumu - TÜIK. (2013). Su Ürünleri İstatistikleri. Ankara: T.C. Gıda Tarım ve Hayvancılık Bakanlığı. 
Uçak, İ., Özogul Y. and Durmuş M. (2011). The effects of rosemary extract combination with vacuum packing on the quality changes of Atlantic mackerel fish burgers. International Journal of Food Science and Technology, 46, 1157-1163.

Vanitha, M., Dhanapal, K., and Reddy, G.V.S. (2015). Quality changes in fish burger from Catla during refrigerated storage. Journal of Food Science and Technology, 52, 1766-1771.

Vanitha, M., Dhanapal, K., Madhavan, N., Vidyasagar, G., Reddy, G.V. and Sravani, K. (2016). Quality changes in fish burger from common carp during refrigerated storage. International Journal of Science, Environment and Technology, 5, 1646 - 1657.

Wojdylo, A., Oszmianski, J. and Czemerys, R. (2007). Antioxidant activity and phenolic compounds in selected herbs. Food Chem., 105, 940-949.

Yerlikaya, P., Gokoglu, N. and Uran, H. (2005). Quality changes of fish patties produced from anchovy during refrigerated storage. Eur. Food Res. Technol., 220, 287-291.

Yi-Chen, Ch., Nguyen, J., Semmens, K., Beamer, S. and Jaczynski, J. (2008). Chemical changes in omega-3 enhanced farmed rainbow trout (Oncorhynchus mykiss) fillets during abusive-temperature storage. Food Control. 19, 599-608.

Yildiz, M., Sener, E. and Timur, M. (2008). Effects of differences in diet and seasonal changes on the fatty acid composition in fillets from farmed and wild sea bream (Sparus aurata L.) and sea bass (Dicentrarchus labrax L.). International Journal of Food Science and Technology, 43, 853- 858.

Zamir, M., Qasim, R., and Ullah, A. (1998). Changes in physical and chemical constituents of crab meat during storage at refrigerator temperature $\left(7 \pm 2^{\circ} \mathrm{C}\right)$. Pak. J. of Pharma. Sci., 11, 27-33.

Zhang, L., Lin, Y. H., Leng, X. J., Huang, M. and Zhou, G. H. (2013). Effect of sage (Salvia officinalis) on the oxidative stability of Chinese-style sausage during refrigerated storage. Meat Science, 95, 145- 150. 


\title{
الملخص العزبي
}

\section{تأثير الزيت العطرى للمريمية على الجودة التركيبية لبرجر سمك الأنثوجة

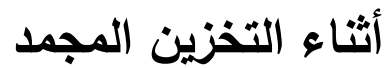

\author{
أحمد السعيد جمعه - طارق محمد سرور - أحمد السبا عبدالله \\ كليه الزراعة سابا باشا جامعة الإسكندرية
}

كان الغرض من هذه الدراسـة هو معرفة الجودة التركيبية والتقييم الحسي لبرجر أسماك الأنشوجة الأوروبي المحضّر

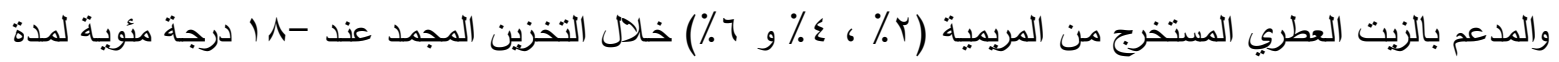
ع أشهر

تم استخلاص الزيوت العطرية من أوراق المريمية بطريقة التقطير وبه و وتحليلها بواسطه Gydrodistilation. وتم إجراء تحليل للتركيب الكيميائي التقريبي ، وتركيب الأحماض الدهنيـة للزيوت المستخلصـة من عينات البرجر ، والتقييم الحسي على عينات برجر السمك المحضرة في بدايـة التحضير أي طازجا قبل التخزين وبعد تخزين لمدة ؛ أنثهر عند -1 ا درجة مئوية ، في حين تم تحليل الجودة التركيبية (رقم البيروكسيد PV والأحماض الدهنية الحرة FFA) تم تقديرها بشكل دوري كل شهر خلال فترة التخزين. كان هناك انخفاض كبير في الرطوبة والبروتين والدهون لبرجر الأسماك سواء كانت المدعمه أو غير المدعمه بالزيت العطرى للمريمية بعد تخزين ع أنثهر علي -1 ا درجة مئوية. كما أظهرت النتائج التي نم الحصول عليها أن PFA و كانت أقل زيادة في عينات برجر الأسماك المدعمة بالزيت العطرى للمريمية عن العينات الكنترول غير المضاف إليها الزيت العطرى.

أدى الزيت العطري للمريمية الذي تم التعرف علي مركباته إلى تحسين نوعية برجر السمك بشكل كبير من خلال الفساد

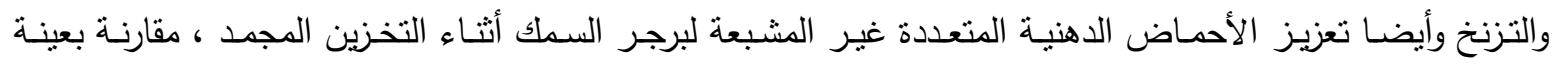
الكنترول. وقد تكون هذه النتائج بسبب تأثنر مضادات الأكسدة للمركبات النشطة بيولوجيا (ألفا- ثوجون ، الكافور ، ألفا- بينين و ثثوجون) الموجودة في الزيت العطري للمريمية.

وخلاصة القول فإن تدعيم برجر سمك الأنشوجة بالزيت العطري للمريمية أظهرت تأثنيرًا إيجابيًا على الجودة التركيبية

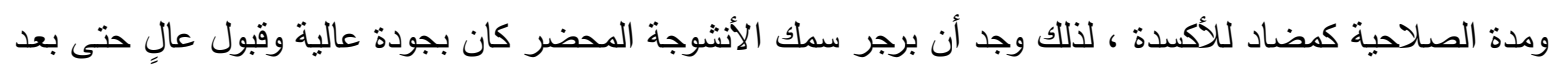

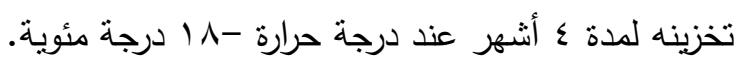


